\title{
A global comparative overview of the legal regulation of stem cell research and therapy: Lessons for South Africa
}

\author{
M Nöthling Slabbert, ${ }^{1}$ BA, BA Hons, MA, DLitt, LLB, LLD; M S Pepper, ${ }^{2}$ MB ChB, PhD, MD \\ 'Department of Jurisprudence, School of Law, University of South Africa, Pretoria, South Africa \\ ${ }^{2}$ Department of Immunology, Faculty of Health Sciences; Institute for Cellular and Molecular Medicine and MRC Extramural Unit for Stem Cell Research \\ and Therapy, University of Pretoria, South Africa; Department of Genetic Medicine and Development, Faculty of Medicine, University of Geneva, \\ Switzerland
}

Corresponding author: M Nöthling Slabbert (slabbmn@unisa.ac.za)

\begin{abstract}
Stem cell research and its potential translation to regenerative medicine, tissue engineering and cell and gene therapy, have led to controversy and debates similar to the calls nearly 25 years ago for a ban involving recombinant DNA. Global legislative efforts in this field have been characterised by many legal, ethical and practical challenges, stemming from conflicting views regarding human embryonic research and cloning. National policy and regulatory developments have primarily been shaped by different understandings of relevant scientific objectives, as well as those relating to the moral and legal status of the human embryo, which have been used to justify or limit a range of permissible activities. Legal obscurity in this field, a consequence of inconsistent or vague legislative responses at a national and international level, leads to negative results, which include, among others, ethical violations; lack of collaboration and co-operation among researchers across national borders; stunted scientific progress; lack of public trust in stem cell research; proliferation of untested 'stem cell therapies'; and safety issues. The purpose of this article is to explore the legal regulation of stem cell research and therapy globally, by comparing the permissibility of specific stem cell research activities in 35 selected jurisdictions, followed by a comparison of the regulatory approaches with regard to stem cell-based products in the European Union and the USA. A clearer understanding of the global regulatory framework will assist in formulating more effective legal responses at a national level and in navigating the uncertainties and risks associated with this complex and evolving scientific field.
\end{abstract}

S Afri J BL 2015;8(2 Suppl 1):12-22. DOI:10.7196/SAJBL.8004

Few advances in medical research have generated as much interest and controversy as those relating to stem cell research and its potential applications in cell and gene therapy, regenerative medicine and tissue engineering. Recent techniques involving induced pluripotent stem cells (iPSCs) and human somatic cell nuclear transfer (SCNT) have raised new ethical and legal questions. The predominant early focus on an 'embryo-centric' approach in this field is slowly being overtaken by an approach focused on the globalisation of research and a concomitant need for'policy interoperability.[1]

Globally, policies and legislation regulating these developments are complex and varied, both within and between jurisdictions, described by some authors as 'a patchwork of patchworks.[2] In addition to variation in national laws and policies with regard to biomedical research and the development of therapeutic applications, variation also exists with regard to other related activities, such as research funding, normative and ethical principles and standards, governance mechanisms, quality assurance and access to stem cell material and data. ${ }^{[3]}$ The regulatory environment is also deeply influenced by social, religious, cultural, economic, historical, ideological and political factors. Competing interests and values promoted and propagated by various agents from, among others, the scientific community, political parties, consumer organisations, interest groups (patient groups, religious organisations and pro-life organisations), the media and the general public, are also relevant. ${ }^{[4]}$ Moral perceptions regarding the human embryo have shaped and informed substantive requirements and procedural safeguards regarding the use of human embryonic stem cells (hESCs) in many jurisdictions. ${ }^{[5]}$

National policy development in this field is guided by international and regional instruments, guidelines and regulations that span biomedical research and related activities, adding a further layer of complexity. The United Nations Educational, Scientific and Cultural Organisation (UNESCO), Council of Europe and the EU have all addressed aspects of stem cell research and its clinical applications through various reports, treaties, resolutions, declarations and guidelines. Guidelines and recommendations by international organisations, such as the Council for International Organisations of Medical Science (CIOMS), the Hinxton Group, the International Consortium of Stem Cell Networks (ICSCN), the International Stem Cell Forum (ISCF) and the International Society for Stem Cell Research (ISSCR) are an instructive resource for policymakers. Nonetheless, human stem cell research, which involves the embryo and its clinical translation, remains a matter for national policy and lawmakers.

The impact of conflicting regulatory regimens is manifold and may affect, among others, the conduct of research, efficiency, collaboration, the clinical translation and commercialisation ${ }^{[6]}$ of research. ${ }^{[3]}$ Although regulatory variation is a natural consequence of heterogeneous contexts, unintended and unforeseen consequences may arise in areas where there are legal regulatory lacunae. One example is the need to balance innovative therapies with rigorous oversight and regulation in the exploitation of vulnerable patients through unproven and potentially harmful stem cell treatments 
in jurisdictions where the regulatory frameworks are ineffective or ambiguous. ${ }^{[7]}$ The most common response to policy variance is a call for the development of harmonised legal and ethical standards. ${ }^{[1]}$

A clearer understanding of the comparative global regulatory framework will assist in determining the scope of policy convergence or consistency that is required in order to navigate more efficient and ethical research and research collaboration in this field, as well as identify strategies to address these differences that may impede scientific progress and innovation. ${ }^{[2]}$ It will also enable specific areas in the field to be harmonised, which could lead to improved policy interoperability. ${ }^{[2]}$ Improved policy interoperability is possible when harmonisation of regulatory approaches is the focus (which doesn't require similarity but rather compatibility) ${ }_{1}^{[8]}$ instead of standardisation (which focuses on uniformity of approaches). ${ }^{[1]}$

The purpose of this article is hence to explore the international legal regulatory framework by comparing selected national approaches toward human stem cell research and therapy by focusing on restrictions or permissions with regard to specific research activities. The different national approaches are best understood in terms of a continuum with the most liberal and permissive regulatory regimens at one end (e.g. those that permit embryo research and the derivation of hESC from various sources and technologies, such as SCNT) and those that prohibit embryo research and related activities (e.g. the use of excess IVF embryos in hESC research) at the other. Surprisingly, jurisdictions with common political, legal, cultural and religious contexts may have very different policy approaches with regard to hESC research. ${ }^{[2]}$

On a global front, the development of therapeutic stem cell applications, similar to that of stem cell research, is likewise characterised by legal uncertainty, and regulatory frameworks are under revision to cater for the unique challenges posed by translational stem cell research, which include efforts to harmonise guidelines relating to safety, efficacy, quality and the development of common technical requirements.

The comparisons drawn in this paper will assist in guiding future legislative developments in the fields of stem cell research and its clinical translation in South Africa.

\section{Ethical issues \\ Moral status of human embryo}

The moral and legal status of the human embryo has always been clouded in controversy. A recent study that explored public perceptions regarding the moral status of the human embryo in nine European countries is no exception. Statements describing the embryo as a cluster of cells (e.g. the relative majority view in Denmark and the UK) were contrasted to others that accord the human embryo the same moral status as other human beings (more prevalent in Austria, Germany, Poland, and Italy). ${ }^{[9]}$

Moral views on the human embryo are informed by the specific significance that persons attach to different stages of human embryonic development ${ }^{[10]}$ such as fertilisation, when the primitive streak develops, when the fetal heart begins to beat, when mental functioning of the fetus commences, when the fetus becomes viable outside the womb, sustained with the help of technology, or when the child is born and able to breathe independently. ${ }^{[11]}$ These moral perceptions may explicitly or implicitly influence views regarding the possible uses and creation of human embryos for research purposes, and ultimately reflect society's understanding of, trust in and expectations and reservations regarding scientific advances in this field. These important embryonic developmental milestones may perhaps not be useful in answering the question of when the law should recognise the embryo or fetus as a legal person to whom the full panoply of civil or constitutional rights should apply, but become relevant when demarcation lines are drawn for research activities involving the human embryo. For example, many jurisdictions agree on a 14-day limit following fertilisation, after which embryos may not be permitted to develop further in vitro. ${ }^{[10]}$ An embryo beyond 14 days' development is unlikely to implant in a woman's womb.

The ambivalence regarding the embryo is reflected in an array of definitions across jurisdictions, with some defining the human embryo in relation to a specific time of embryonic development (e.g. eight weeks from the moment of conception, e.g. South Africa, ${ }^{[12]}$ Australia, ${ }^{[13]}$ India ${ }^{[14]}$ and Singapore $\left.{ }^{[15]}\right)$, others stating its definitions in broad time frames (e.g. a 'fertilised ovum at all stages of development', e.g. Iceland, Estonia, UK, Finland and South Korea), and those that avoid references to gestational development, focusing instead on the capacity of the embryo to develop into a human being (e.g. New Zealand, Belgium, Japan and Germany). ${ }^{[16]}$ In a ruling on 18 December 2014, ${ }^{[17]}$ the Court of Justice of the EU clarified the status of embryos created through parthenogenesis (having only one set of DNA and unable to develop into human beings) by confirming that these parthenotes are excluded from the definition of a 'human embryo' as contained in Directive 98/44/ EC of 6 July 1999 of the European Parliament and Council on the legal protection of biotechnological inventions, and are hence patentable. ${ }^{[18]}$

The hESC research has been regarded as ethically controversial by many because it is associated with the destruction of the human embryo i.e. when pluripotent stem cell lines are derived from the inner cell mass (ICM) of the 5 to 7-day-old pre-embryo or blastocyst. The issue at stake, referred to above, is whether the embryo is merely a clump of cells or whether its (developmental) potential to become a human being bestows on it all the qualities and characteristics associated with human personhood (and consequently legal protection as a legal subject). The answers to these questions will determine the limits on the research activities that may be morally (and legally) permitted with regard to human embryos. Secondly, the source of these human embryos or hESCs is also relevant. For example, in the case of embryos, were they created solely for research purposes or were they excess embryos left over after in vitro fertilisation? If not used and destined to be discarded in any event, would it be morally justifiable to use them in medical research aimed at ultimately benefiting the greater collective? Many jurisdictions insist on the destruction of human embryos used for research purposes, before 14 days of development (time at which the primitive streak appears).

The human embryo is not the only source of pluripotent stem cells. Pluripotent stem cells can also be derived from oocytes using specific techniques, such as SCNT. However, this process also requires development to the blastocyst phase in order to harvest ICM cells for creating ES cells. With regard to oocyte donation for research, this carries specific medical risks when the oocytes are retrieved. In addition, ethical concerns arise relating to the donation of oocytes 
for research, as well as human reproduction and the protection of the reproductive interests of women undergoing infertility treatment. ${ }^{[19]}$ Compliance with research governance requirements, informed consent procedures, as well as issues revolving around reimbursement or payment of gamete or embryo donors, is a key ethical consideration. ${ }^{[8]}$

\section{Reproductive and therapeutic cloning}

The creation of stem cells through SCNT is another contested issue. This procedure, which entails the removal of nuclear DNA from an unfertilised oocyte and replacing the removed DNA with the nuclear DNA from a somatic donor cell, was successfully carried out for the first time using human cells in 2013. ${ }^{[20]}$ The reprogrammed oocyte containing the replaced DNA (genetically identical to the DNA of the donor) is stimulated to divide and develop into a blastocyst from which hESCs are harvested to create a stem cell line genetically identical to that of the cell donor. This technique allows researchers to develop genetically identical or compatible tissue for successful autologous tissue transplantation procedures. SCNT is controversial for two reasons. First, the harvesting of ICM cells from the blastocyst to create ES cells, and second because it may lead on to 'cloning' or the reproduction of a genetically identical organism. The intentional creation of embryos using this technique in humans (but not in domestic animals) is condemned for a number of reasons, namely that it diminishes human individuality and integrity, impacts on the freedom, identity and dignity of the human person (in the sense that multiple identical copies of the same DNA are possible), as well as human reproductive autonomy (e.g. that an embryo is created with only one genetic parent to which the embryo would be asymmetrically and genetically identical). Cloning furthermore raises the prospect of eugenics, for example the creation of offspring with certain desired and genetically enhanced characteristics, which will take society beyond therapy into very dangerous and unchartered terrain. These concerns raise vexing questions that are fundamental to our understanding of humanity, human identity, and inviolability of the human person, human reproduction and human dignity. Strong opposition globally to cloning led to a world-wide ban on reproductive cloning in humans, ${ }^{[2]]}$ and as a consequence has cast a shadow on the use of SCNT, without distinguishing between 'therapeutic cloning' and 'reproductive cloning'. As a technique, SCNT may produce a cloned embryo, but the purpose of the process (e.g. research, therapy or reproduction) is a separate matter.

There is also some misunderstanding regarding the difference between 'therapeutic cloning' and 'reproductive cloning'. The firstmentioned is aimed at using the ES cells derived from SCNT in experiments focused on understanding disease and developing treatments for disease and not at creating a living (cloned) baby, as would be the goal of the latter. To date, no conclusive evidence exists that a human being has ever been cloned successfully, despite numerous claims in this regard over the past decade. ${ }^{[22]}$

\section{Oocyte donation}

Carrying out SCNT requires oocytes, which have to come from female egg donors. Donating oocytes through hyper-ovulation is an invasive, time-consuming and painful process. Altruistic oocyte donation is therefore less common than sperm donation. For this reason, and to counter the demand for oocytes, it has been suggested that women donating oocytes receive, in addition to the conventional 'out-ofpocket expenses', fair compensation for physical discomfort, subject to strict ethical guidelines. ${ }^{[23]}$ The South Korean Woo Suk Hwang scandal in 2006 best illustrates some of the more serious ethical risks associated with oocyte donation, namely inappropriate payment to oocyte donors (laboratory staff), undue influence on these female employees to donate oocytes, as well as a high incidence of medical complications following the oocyte donation. ${ }^{[24]}$

Fetal tissue that becomes available after abortion is another source of pluripotent stem cells. Apart from the moral issues relating to the source of these cells, i.e. abortion, the donation of this type of tissue is generally only permitted after the decision to terminate a pregnancy has been made. ${ }^{[19]}$

\section{Induced pluripotent stem cells}

Induced pluripotent stem cells refer to somatic cells that can be reprogrammed to form pluripotent cells. As the reprogramming of these cells does not involve human embryos or oocytes, iPSCs are generally regarded as ethically unproblematic, as the concerns outlined above are absent. Obtaining the somatic cells (e.g. through a skin biopsy) is considered to be non-invasive when compared to the donation of oocytes used in the SCNT procedure. Concerns related to the use of iPSCs include possible downstream uses of the iPSC derivates, which may include the genetic modification of cells, large scale genomic sequencing, the sharing of cell lines among researchers, the possibility of deriving gametes in vitro from iPSCs and the commercialisation of applications involving the cells. ${ }^{[19]}$ Recent studies have demonstrated the potential of iPSCs to differentiate into both male and female germ cells in different species. One of these includes the development of functional gametes and offspring in mice. ${ }^{[25]}$ This example raises complex legal and ethical issues relating to the sequence and process of reproduction and genetic parentage, not to mention informed consent issues, concerns regarding cloning, as well as the potential to create an embryo by donors that may be unaware of such a possibility or attempt.

\section{Intellectual property issues}

The question of intellectual property rights in the context of stem cell research is also fraught with ethical controversy, specifically concerning the patenting of living things or products of nature. In contrast to purified or isolated stem cells that are generally patentable as research tools, including the methods and reagents to grow and generate stem cell lines, there has been variance in legal approaches regarding the patenting of hESCs themselves (as living things) across jurisdictions, notably between Europe, the USA and Japan. ${ }^{[26]}$ In 2008, the Expanded Appeal Board of the European Patent Office ruled that hESC lines for industrial or commercial purposes are not eligible for patent protection in Europe. ${ }^{[27]}$ This ruling (in sharp contrast to the position in the USA) was followed by a ruling of the European Court of Justice in 2011 that banned patents on procedures involving the destruction of human embryos at any stage, including procedures used for the creation of hESC lines, as well as those using previously derived cell lines. ${ }^{[28]}$

Intellectual property issues touch on a legal conundrum regarding the right of donors to retain property or proprietary interests in their own tissues, embryos or genetic material. The most commonly accepted view rejects property claims of research participants to 
biological material that they donated to research, despite the fact that their samples may lead to very profitable cell-line applications in which they will not share. ${ }^{[29]}$ This may appear inequitable and conflicting if one considers the continuing rights of donors regarding the uses and secondary uses involving their tissue samples. On the other hand, property rights in embryos were (implicitly or explicitly) recognised by courts in the USA, ${ }^{[30]}$ and also in respect of stored gametes (the USA, ${ }^{[31]}$ Australia ${ }^{[32]}$ and the UK ${ }^{[33]}$ ).

\section{Informed consent and other issues}

More general ethical concerns relevant to the field of stem cell research and therapy are those relating to informed consent, specifically considering that cell lines may potentially be used indefinitely for future research not yet conceived. Questions arise as to the circumstances under which currently stored samples may be used for further stem cell research without consent, as well as the right of donors to withdraw their participation at any time during the research. Guideline documents on this issue differ, with some suggesting that donors can withdraw consent until the creation of an anonymised cell line, ${ }^{[34]}$ and others until an embryo or blastocyst is used in the derivation of a cell line. ${ }^{[35]}$ If donors may withdraw consent to participate in research once a cell line is created, this may drastically impact on further research. There is generally strong support for the right of withdrawal to endure. ${ }^{[36]}$ Induced pluripotent stem cell research raises unique consent challenges that may require a specialised approach to consent (e.g. one that details common uses and possible uses of cell lines that donors may find problematical, for example producing human-animal chimeras and the derivation of human gametes). ${ }^{[37]}$

Protecting the privacy and confidentiality of donors of tissues, gametes or embryos in the context of stem cell research always remains a concern, specifically as far as the potential traceability of stem cell lines is concerned. ${ }^{[3]]}$ The issue of how to address incidental findings (i.e. that a donor suffers or is likely to suffer from a specific disease) is another concern.

\section{Stem cell research: Regulatory approaches}

With the permissibility and prohibition of specific activities as the yardstick for comparison, this section provides a broad global overview of distinctive legislative and policy approaches relating to stem cell research (Table 1). As noted earlier, these approaches reflect intricate and nuanced differences, which should be interpreted within the wider context of each jurisdiction's legal, socio-economic, political and cultural tradition. In addition, the design of each regulatory framework may be influenced by specific or general statutory provisions or professional guidelines (as in India, for example) or by a combination of both. ${ }^{[16]}$ All the jurisdictions listed below prohibit the reproductive cloning of human beings. The specific research activities involving embryos selected for comparison below are likewise not consistently and similarly articulated in the different legal and policy documents across these jurisdictions, with the result that in some instances, the permissibility or prohibition of these activities was deduced from more general proscriptions. For example, a prohibition on the creation of human embryos for research or therapeutic purposes would include a prohibition of the use of SCNT to create an embryo.
Issues, on which policy variances across these jurisdictions are most evident, are the moral (and legal) status of the human embryo, the patenting of human tissues and payment of tissue and gamete donors. On the other hand, consensus is more uniform on the issues of prohibition of reproductive cloning, research standards, clinical readiness, cell line quality and scientific integrity. ${ }^{[2]}$ Matters related to stem cell therapy (as opposed to research) will be considered separately, since this is a separate debate with an additional set of parameters.

\section{Liberal}

At the one end of the spectrum are jurisdictions that permit a number of activities with regard to stem cell research, which include the creation and use of embryos and derivation of stem cell lines from various sources for a number of purposes. Liberal approaches, through tight regulations, generally permit SCNT under specific circumstances and are subject to procedural rules and governance mechanisms. The overall objective of the liberal frameworks is to advance scientific progress, while at the same time taking into account public concerns.

Jurisdictions belonging to this category are, for example, Australia, Belgium, India, Iran, Israel, Japan, Singapore, South Korea, South Africa, Spain, Sweden, Taiwan, the UK and selected states in the USA (e.g. California, Illinois, lowa, Maryland and New Jersey).

\section{Moderate}

Jurisdictions adopting a moderate approach to stem cell research allow a measure of flexibility and typically permit a range of activities, subject to specific regulatory checks and balances. Jurisdictions belonging to this category attempt to strike a regulatory compromise between contradicting or diverse interests. Some of these jurisdictions permit research using surplus IVF embryos under specific circumstances, but may prohibit hESC derivation from other sources or involving specific techniques, such as embryos created using SCNT. The use of excess or surplus embryos is generally subject to conditions relating to informed consent of the donors, payment of donors and restrictions on the use of embryos beyond 14 days.

Countries whose stem cell regulatory frameworks may be considered moderate are, for example, Brazil, Canada, Denmark, Finland, France, Greece, the Netherlands, New Zealand, Norway, Slovenia, Switzerland, and some states in the USA (e.g. Arkansas, Montana, and Virginia).

\section{Prohibitive}

Jurisdictions characterised as having adopted a restrictive approach expressly prohibit the creation and use of embryos for research purposes or for the derivation of hESCs, or may allow the use of imported hESC lines under tightly controlled and limited conditions. Although some of these countries do not explicitly prohibit or ban therapeutic cloning, the creation of embryos for research purposes is prohibited, which implies curtailment of therapeutic cloning. The protection of human life and dignity in the contexts of eugenics and abortion is a specific legal concern in some of these jurisdictions (e.g. Germany and Ireland).

Countries that fall into this category are Austria, Costa Rica, Germany, Ireland, Italy, Lithuania and some states in the USA (e.g. Oklahoma). 
Table 1. Stem cell research: Regulatory approaches

\begin{tabular}{|c|c|c|c|c|c|}
\hline $\begin{array}{l}\text { Jurisdiction } \\
\text { *Legal position unclear, e.g. whether permitted } \\
\text { or prohibited } \\
{ }^{* *} \text { No specific legislation regarding hESC research }\end{array}$ & $\begin{array}{l}\text { Permit creation } \\
\text { of human } \\
\text { embryos for } \\
\text { research, } \\
\text { including SCNT }\end{array}$ & $\begin{array}{c}\text { Prohibit creation } \\
\text { of human } \\
\text { embryos, } \\
\text { including SCNT }\end{array}$ & $\begin{array}{c}\text { Permit } \\
\text { derivation } \\
\text { of hESC lines } \\
\text { from excess IVF } \\
\text { embryos } \\
\end{array}$ & $\begin{array}{c}\text { Prohibit } \\
\text { derivation of } \\
\text { hESCs }\end{array}$ & $\begin{array}{c}\text { Prohibit } \\
\text { derivation of } \\
\text { hESCs, but permit } \\
\text { importation of } \\
\text { hESC lines } \\
\end{array}$ \\
\hline Australia & $\sqrt{ }$ & & $\sqrt{ }$ & & \\
\hline Austria & & $\sqrt{ }$ & & $\sqrt{ }$ & \\
\hline Belgium & $\sqrt{ }$ & & $\sqrt{ }$ & & \\
\hline Brazil & & $\sqrt{ }$ & $\sqrt{ }$ & & \\
\hline Canada & & & $\sqrt{ }$ & & \\
\hline China & $\sqrt{ }$ & & $\sqrt{ }$ & & \\
\hline Costa Rica & & $\sqrt{ }$ & & $\sqrt{ }$ & \\
\hline Denmark & & $\sqrt{ }$ & $\sqrt{ }$ & & \\
\hline Finland & $*$ & $*$ & $\sqrt{ }$ & & \\
\hline France & & $\sqrt{ }$ & $\sqrt{ }$ & & \\
\hline Germany & & $\sqrt{ }$ & & $\sqrt{ }$ & $\sqrt{ }$ \\
\hline Greece & & $\sqrt{ }$ & $\sqrt{ }$ & & \\
\hline India & $\sqrt{ }$ & & $\sqrt{ }$ & & \\
\hline Iran & $\sqrt{ }$ & & $\sqrt{ }$ & & \\
\hline Ireland & & $\sqrt{ }$ & & $\sqrt{ }$ & \\
\hline Israel & $\sqrt{ }$ & & $\sqrt{ }$ & & \\
\hline Italy & & $\sqrt{ }$ & & $\sqrt{ }$ & $\sqrt{ }$ \\
\hline Japan & $\sqrt{ }$ & & $\sqrt{ }$ & & \\
\hline Lithuania & & $\sqrt{ }$ & & $\sqrt{ }$ & \\
\hline Mexico & $\sqrt{ }$ & & $\sqrt{ }$ & & \\
\hline Netherlands & & $\sqrt{ }$ & $\sqrt{ }$ & & \\
\hline New Zealand & & $\sqrt{ }$ & $\sqrt{ }$ & & \\
\hline Norway & & $\sqrt{ }$ & $\sqrt{ }$ & & \\
\hline Portugal & & $\sqrt{* *}$ & & & \\
\hline Singapore & $\sqrt{ }$ & & $\sqrt{ }$ & & \\
\hline Slovakia & & $\sqrt{* *}$ & & & \\
\hline Slovenia & & $\sqrt{ }$ & $\sqrt{ }$ & & \\
\hline South Africa & $\sqrt{ }$ & & $\sqrt{ }$ & & \\
\hline South Korea & $\sqrt{ }$ & & $\sqrt{ }$ & & \\
\hline Spain & $\sqrt{ }$ & & $\sqrt{ }$ & & \\
\hline Sweden & $\sqrt{ }$ & & $\sqrt{ }$ & & \\
\hline Switzerland & & $\sqrt{ }$ & $\sqrt{ }$ & & \\
\hline Taiwan & $\sqrt{ }$ & & $\sqrt{ }$ & & \\
\hline UK & $\sqrt{ }$ & & $\sqrt{ }$ & & \\
\hline
\end{tabular}

USA

(variation of laws within states)
No federal ban on hESC research, but restrictions on federal funding before 9 March 2009; federal funding only permitted for non-hESC research or those using hESC lines in existence prior to 9 August 2001. President Obama's Executive Order lifted these restrictions for research involving new hESC lines. No federal funding under $2009 \mathrm{NIH}$ Guidelines for research that creates human embryo for research purposes or destroys a human embryo (human cloning).

\begin{tabular}{ll} 
Arkansas & \\
\hline California & $\sqrt{ }$ \\
\hline Connecticut & $\sqrt{ }$
\end{tabular}

$$
\sqrt{ }
$$

$\begin{array}{ll}\sqrt{ } & \sqrt{ } \\ \sqrt{ } & \sqrt{ }\end{array}$


Table 1. (continued) Stem cell research: Regulatory approaches

\begin{tabular}{|c|c|c|c|c|c|}
\hline $\begin{array}{l}\text { Jurisdiction } \\
\text { *Legal position unclear, e.g. whether permitted } \\
\text { or prohibited } \\
\text { **No specific legislation regarding hESC research }\end{array}$ & $\begin{array}{l}\text { Permit creation } \\
\text { of human } \\
\text { embryos for } \\
\text { research, } \\
\text { including SCNT }\end{array}$ & $\begin{array}{c}\text { Prohibit creation } \\
\text { of human } \\
\text { embryos, } \\
\text { including SCNT }\end{array}$ & $\begin{array}{l}\text { Permit } \\
\text { derivation } \\
\text { of hESC lines } \\
\text { from excess IVF } \\
\text { embryos }\end{array}$ & $\begin{array}{c}\text { Prohibit } \\
\text { derivation of } \\
\text { hESCs }\end{array}$ & $\begin{array}{c}\text { Prohibit } \\
\text { derivation of } \\
\text { hESCs, but permit } \\
\text { importation of } \\
\text { hESC lines } \\
\end{array}$ \\
\hline Illinois & $\sqrt{ }$ & & $\sqrt{ }$ & & \\
\hline lowa & $\sqrt{ }$ & & $\sqrt{ }$ & & \\
\hline Maryland & $\sqrt{ }$ & & $\sqrt{ }$ & & \\
\hline Massachusetts & $\sqrt{ }$ & & $\sqrt{ }$ & & \\
\hline Michigan & & $\sqrt{ }$ & $\sqrt{ }$ & & \\
\hline Montana & $\sqrt{ }$ & & $\sqrt{ }$ & & \\
\hline New Jersey & $\sqrt{ }$ & & $\sqrt{ }$ & & \\
\hline Oklahoma & & $\sqrt{ }$ & & $\sqrt{ }$ & \\
\hline Virginia & & $\sqrt{*}$ & $\sqrt{ }$ & & \\
\hline
\end{tabular}

\section{Stem cell therapy: Regulatory approaches Introduction}

The global regulation of stem cell therapies, similar to that of stem cell research, is characterised by legal uncertainty, with many jurisdictions revisiting regulatory systems to address the needs and challenges posed as cell and tissue therapies emerge. Effective global regulation is hampered by the diverse nature of stem cell-based products and that regulatory regimens differ with regard to the intended clinical use of the cell product, method of clinical delivery and manufacture. ${ }^{[38]}$

The expansion of the harvested cells in vitro to generate a sufficient dose for therapeutic use, regarded as a more-than-minimally manipulated process, has added additional regulatory complexities, and products generated in this way are classified either as advanced therapy medicinal products (ATMPs) (the position in the EU) or biologics (the position in the USA) ${ }^{[9]}$ Regulatory differences between the EU and the USA, for example, relate not only to the clinical trial requirements (e.g. the EU's Clinical Trial Authorisation (CTA) and the Investigational New Drug application (IND) in the USA), but also to the data required to establish quality, safety and efficacy of cell therapies. Existing regulatory frameworks for the donation, procurement, processing and preservation of cells and tissues are often based on the so-called 'conventional pharmaceutical paradigm', which, considering the distinct features of stem cells, introduces obstacles with respect to the safety and efficacy of stem cell lines which are very different from other pharmaceutical products. ${ }^{[39]}$ In addition, novel applications using hESCs or iPSCs may carry specific and unforeseen risks.

We will focus on the regulatory regimens for stem cell-based products in the EU and the USA, as this comparison will best illustrate the regulatory challenges associated with stem cell-based applications.

As this section will show, there is a need for greater harmonisation of regulatory standards and requirements across the world. One example is cell-device combinations, regulated as ATMPs in the EU but as medical devices in the USA, hence requiring different data from clinical trials in each of these instances. Current efforts to harmonise regulatory requirements include the International Conference on
Harmonisation $(\mathrm{ICH}){ }^{[40]}$ and a European Medicines Agency-Food and Drug Administration (EMA-FDA) joint committee. Other instructive non-binding codes of practice or guidelines, referred to above, are those published by international bodies, such as the ISSCR and the Hinxton Group.

\section{European Union}

Medicinal products based on human cells and tissues are classified (Table 2) as ATMPs in the EU (under Regulation (EC) 1394/2007) and can only be authorised for general use by the European Medicines Agency (EMA). The ATMP regulation enabled the European Commission to adopt specific requirements regarding issues such as good clinical practice, good manufacturing practices, the content of marketing authorisation applications, and the traceability of ATMPs. ${ }^{[41]}$

ATMPs include gene therapy medicinal products, somatic cell products and tissue-engineered products. Provision is also made for the establishment of a Committee on Advanced Therapies (CAT), which provides a central cell therapy product evaluation procedure and assesses the quality, safety and efficacy of ATMPs for the final approval by the Committee for the Medicinal Products for Human Use (CHMP). Exempted from the ATMP regulations are products prepared on a 'non-routine' basis and used within the same member state in a hospital as prescribed for an individual patient. ${ }^{[42]}$ This 'hospital exemption' allows patients to receive an ATMP under strictly controlled conditions in circumstances where there is no authorised medicinal product available. The interpretation of the so-called 'hospital exemption' is causing confusion in member states and will be discussed below.

Not all of the manufacturing processes for ATMPs fall under the ATMP regulations when the ATMPs are produced from human tissues or cells. The 2004 European Union Human Tissues and Cells Directive (EUTCD $)^{[43]}$ provides quality and safety standards for human tissues and cells used for therapeutic purposes, and applies to all stages from donation to processing, storage and distribution. Implemented at a national level, it sets out the requirements for the accreditation, designation, authorisation, or licensing for the procurement and testing of the biological material intended for human applications. 
Products containing human tissues or cells (viable or non-viable) cannot be classified as medical devices in the EU in terms of the Council Directive concerning medical devices, ${ }^{[44]}$ despite containing elements of medical devices, unlike the position in the USA (see discussion below)

\section{United States of America}

(Table 3) The US Food and Drug Administration (FDA) is the regulatory authority responsible for the regulation of, among others, therapeutic products, which may include drugs, devices, biological or combination products (containing two or more different regulated components, e.g. drug and device or biologic and device). Regulations in the Code of Federal Regulations (CFR) pertaining to cell therapy products are the Investigational New Drugs (IND) regulations (21 CFR 312), biologics regulations (21 CFR 600), regulations on human cells, tissues and cellular and tissue-based products (HCT/P)s (regulations; 21 CFR 1271), and current good manufacturing practice regulations (21 CFR 211). The FDA's HCT/P regulations create a tiered framework based on sections 351 and 361 of the Public Health Services Act (PHSA). HCT/ $\mathrm{Ps}$, described as articles 'containing or consisting of human cells or tissues that are intended for implantation, transplantation, infusion or transfer into a person' (21 CFR 1271.3(d)), are subject to the HCT/ Ps regulations, unless removed from a patient and implanted into the same patient as part of the same surgical procedure (21 CFR $1271.15(b)) .^{[45]}$

Although subject to the HCT/Ps regulations, no licence is necessary for section $361 \mathrm{HTC} / \mathrm{Ps}$ that meet certain criteria, e.g. if minimally manipulated, intended for homologous use and not combined with any other product, and autologous, e.g. the patient is treated with his or her own cells (21 CFR 1271.10(a)). HCT/Ps not meeting these criteria, however, are also subject to the good tissue practice requirements ${ }^{[46]}$ and will in addition be regulated as drugs, biologics or devices under section 351 of the PHSA (21 CFR 1271.20). Stem cellbased therapies involving more than minimally manipulated cells will mostly fall within the last-mentioned category, even if used for autologous purposes.

The meaning of 'more than minimally manipulated' was highlighted in the USA in a 2014 judgment. This case revolved around the FDA's action against Regenerative Sciences, LLC, who manufactured a product called Regenexx ${ }^{\mathrm{TM}}$, consisting of autologous mesenchymal stem cells manipulated outside of the body and injected back into patients with orthopaedic injuries. The US Circuit Court of Appeals for the District of Columbia held that: (i) the cell mixture used for this procedure contained both a drug and biologic; (ii) it was more than minimally manipulated under section 351 of the PHSA; (iii) it qualified as interstate commerce; and (iv) was hence subject to the regulation and approval of the FDA. ${ }^{[47]}$

In terms of the FDA framework, physicians may administer more than minimally manipulated stem cell products to patients in two ways. The first is permitted in accordance with the FDA's programme for 'expanded access to investigational drugs and biological products for treatment use', better known as 'compassionate use', provided that the product in question is being tested in a present clinical trial and only if expanded access will not interfere with the conduct of clinical investigations. ${ }^{[48]}$ Clinicians are allowed to charge patients to recover direct costs, as well as those administrative costs associated with expanded access use. The second exception is the 'off-label prescribing' of FDA-approved stem cell products, which refers to the prescribing of medicine in a manner that differs from the specified instructions. ${ }^{[49]}$

It is generally accepted in both the EU and USA that the deliberate expansion of cells in culture substitutes more than minimal manipulation. Manipulated autologous cells for structural use, on the other hand, fall within the ambit of somatic cell therapy products and require an 'investigational new drug' (IND) exemption or the FDA license approval.

The FDA facilitates regulatory compliance through guidance documents via the Centre for Biologics Evaluation and Research (CBER). The FDA offers advisory committee meetings which may discuss pertinent questions relating to a particular product or product area. The Office of Cellular, Tissue and Gene Therapies' (OCTGT) own committee, the Cellular, Tissue and Gene Therapies Advisory Committee (CTGTAC), is tasked to discuss cell-therapy products. Various guidance documents provide clarity on specific regulatory issues. For example, HCT/Ps from adipose tissue ${ }^{[50]}$ and minimally manipulated $\mathrm{HCT} / \mathrm{Ps}^{[5]]}$ are the focus of recent FDA draft guidance documents.

\section{Regulatory challenges}

There is no doubt that stem cell-based therapies are developing very fast and that regulatory frameworks should be flexible enough to accommodate the pace of scientific progress. It is generally agreed that more research is necessary on the procedures to establish the safety and efficacy of stem cell products and the prediction of potential risks. Most regulatory models seem to follow a risk-based approach that focuses on both extrinsic issues (e.g. donor selection, sample procurement to limit risk of transmitting communicable diseases, and manufacturing and handling practices) and intrinsic issues (such as cell origin). Safety issues (following reports of serious adverse events) seem to receive more attention than efficacy issues. This makes the conventional pharmaceutical regulatory model an uncomfortable fit for the clinical translation of the cells into products.

There is a need for the global harmonisation of guidelines covering a broad range of issues, which due to the limited scope of this article, cannot be discussed. Despite broadly similar regulatory requirements and procedures with regard to product pre-market approval processes (to establish safety, efficacy and quality), regulation of clinical trials using Good Clinical Practice (GCP) and regulation and licensing of manufacturing using Good Manufacturing Practice (GMP) (primarily the result of increased harmonisation of therapeutic product regulation under the auspices of the $\mathrm{ICH}$ of Technical Requirements for Registration of Pharmaceuticals for Human Use), specific disparities remain. Two examples are the issues of donor eligibility and the suitability of stem cell lines for use in clinical trials and subsequent commercialisation. ${ }^{[52]}$ The legal regulation of human tissue (governing the procurement, use and disposal of human tissue) and tissue establishments across jurisdictions is also diverse, creating additional obstacles.

Harmonisation attempts are furthermore hampered by ambiguity and uncertainty with regard to the following issues:

\section{Product classification}

The scope of what constitutes cell-based products is unclear. The term 'stem cell-based products' refers to 'products intended to be administered to a patient', which 'contain or are derived from stem 


\section{Table 2. EU regulatory framework (selected documents)}

EU
Regulation/directive
Regulation (EC) No. 1394/2007
Regulation (EU) No. 536/2014

Directive 2004/23/EC

Directive 2006/17/EC

Directive 2003/94/EC

Directive 2001/83/EC

Directive 2009/120/EC

\section{EMA \\ CHMP \\ CAT} Directive 2001/20/EC human tissues and cells human use 2004/27/EC
Of the European Parliament and of the Council on ATMPs

Of the European Parliament and of the Council on clinical trials on medicinal products for human use, repealing

EUTCD, which establishes the standard quality, donation safety, harvesting, tests, processing, preservation, storage, and distribution of human tissues and cells

Implementing Directive 2004/23/EC of the European Parliament and of the Council as regards certain technical requirements for the donation, procurement and testing of

Good manufacturing practice for medicinal products for human use and investigational medicinal products for

Medicinal products for human use (includes 2003/63/EC,

and advanced therapy regulation).

Commission Directive 2009/120/EC amending Directive 2001/83/EC of the European Parliament and of the Council on the community code relating to medicinal products for human use as regards ATMPs.

\section{Table 3. USA regulatory framework (selected documents)}

\begin{tabular}{|c|c|}
\hline USA & $\begin{array}{l}\text { FDA } \\
\text { CBER } \\
\text { OCTG) } \\
\text { CTGTAC }\end{array}$ \\
\hline Regulation & $\begin{array}{l}\text { Legislation: } \\
\text { Public Health Service Act, sections } 351 \text { and } 361 \text { [42 USC 264] } \\
\text { Regulations for Investigational New Drugs (IND), Code of Federal } \\
\text { Regulations, Part } 312\end{array}$ \\
\hline 21 CFR $1271^{*}$ & Human Cells, tissue, cellular- and tissue-based products \\
\hline 21 CFR 210 & $\begin{array}{l}\text { Current good manufacturing practice in manufacturing, } \\
\text { processing, packaging or holding of drugs }\end{array}$ \\
\hline 21 CFR 211 & $\begin{array}{l}\text { Current good manufacturing practice for finished } \\
\text { pharmaceuticals }\end{array}$ \\
\hline $\begin{array}{l}21 \text { CFR } 600 \\
21 \text { CFR } 610\end{array}$ & $\begin{array}{l}\text { Description of general safety and sterility tests administered by } \\
\text { parenteral routes (note, this is not a safety test of the product itself). }\end{array}$ \\
\hline $\begin{array}{l}21 \text { CFR } 314 \\
21 \text { CFF } 312\end{array}$ & Adequate and well-controlled clinical trials \\
\hline $\begin{array}{l}21 \text { CFR } 50 \\
21 \text { CFR } 56\end{array}$ & Subpart B. Informed consent of human subjects \\
\hline 21 CFR 58 & Good laboratory practices for nonclinical laboratory studies \\
\hline
\end{tabular}

cells. ${ }^{\prime 53]}$ These include three therapeutic concepts for the use of stem cells, namely direct administration, transplantation of differentiated stem cell progeny, and tissue engineering ${ }^{[53]}$ As far as direct administration is concerned, stem cells are introduced either locally or systemically into a patient's body, after which the cells migrate to the intended site where differentiation into the appropriate cell type takes place. ${ }^{[53]}$ With transplantation, the stem cells are first cultivated in vitro, followed by their differentiation into the desired tissue type, before being transplanted into the patient. In the case of tissue engineering, cells are seeded or implanted onto a scaffold or matrix, where the combination approximates the desired tissue. ${ }^{[53]}$ Adding to the complexity is the fact that in any of these applications, cells from different sources may be used (as discussed earlier in this article), resulting in the eventual product being classified as either allogeneic (cells from a donor are used), autologous (recipient's own cells are used), or xenogeneic (cells from another species are used). ${ }^{[53]}$ The unique nature of these products means that methods and standards traditionally used with regard to conventional pharmaceutical products to ensure the safety, efficacy and quality of the stem cell-based products, may not be sufficient. Combination products are also addressed very differently across jurisdictions. Although products falling within two or more categories are normally assessed according to their principal or primary mode of action (PMOA), assessed on a case-by-case basis, this assessment cannot always be made with certainty and may lead to undesired results..$^{[53]}$

Product categories within the EU and the USA have their own challenges. In the EU, for example, ATMPs include three types of medicinal products, namely gene therapies, somatic cell therapies, and tissue engineered products. It is often difficult to determine to which of these categories a product belongs. Another controversial assessment is the question of whether manipulation of a living material is minimal or substantial. Moreover, some of the new biological products could easily fit one or more of the categories of medicines, medical devices, cosmetics, or tissues and cells. Regulatory discrepancies in this regard may mean that one product may be subject to different requirements across the EU. These disparities will negatively impact on incentives to develop ATMPs by discouraging investments, distorting competition between developers and impeding the free movement of these

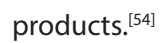

\section{'Minimally manipulated v. 'substantially manipulated'}

The interpretation of 'minimally manipulated' stem cells is important for various reasons. 
Most significantly, if the stem cells were more than minimally manipulated, the product is legally destined for the more stringent and expensive 'drug pathway' for broad clinical use, which includes, for example, the controlling of the resulting products through mandated premarket testing for safety and efficacy in specified indications and the conducting of a series of registered multiphase (I-III) clinical trials. The Regenexx ${ }^{\mathrm{TM}}$ case, referred to above, prompted the publication of guidelines by the FDA in December 2014 on minimally manipulated cells. ${ }^{[5]}$ For example, manipulations with adipose tissue (e.g. isolating cells from adipose tissue) will in future be considered to be more than minimally manipulated, as this changes the original characteristics of the cells. ${ }^{[55]}$ These guidelines will be instructive for other jurisdictions where the regulatory framework for stem cell-based therapies is immature or silent on a range of issues relating to the regulation of cell based therapies.

\section{Treatments or products exempted from product regulation}

The legal regulation of stem cell treatments, which are exempted from product regulation, is likewise inconsistent across jurisdictions. Products assessed as having minimal risks and not posing serious safety concerns are normally subject to limited regulatory oversight. Autologous cells that: (i) have not been manipulated extensively or combined with other articles; (ii) are intended for homologous use in functionally compatible tissues, and/or (iii) are harvested and transplanted as part of the same surgical procedure, are generally exempted from product regulation, such as hematopoietic stem cell transplants aimed at restoring bone marrow function. ${ }^{[56]}$ In this regard, different interpretations exist regarding the level of manipulation (e.g. the exact meaning of 'minimally' or 'more than minimally manipulated') and the intended use of the cells across jurisdictions, as well as definitions used to describe these processes. Concepts such as 'homologous' or 'non-substantial' are likewise not always clearly defined, leading to diverse assessments of which cells are classified as posing a 'minimal risk' and those requiring more stringent regulation. ${ }^{[56]}$

This uncertainty also extends to more than minimally manipulated cell-based products, regulated as drugs in exceptional instances where patients are provided with access to medicinal products lacking the relevant evidence required for market licensing. These exemptions are regulated differently across jurisdictions and under different descriptions, such as 'compassionate use' or 'special access' provisions (e.g. in the USA). These exceptions fall within the scope of the regulation of medical practice, often with additional oversight mechanisms, such as approval from an institutional review board, or as is the case in the EU, under the so-called 'hospital exemption', referred to above. The scope of the 'hospital exemption' is also not clearly and uniformly understood in the different member states and related terms, such as 'prepared on a non-routine basis', referred to in the discussion on the EU above, are equally obscure. ${ }^{[57]}$

The legal uncertainty in this context is underscored by a 2014 decision of the European Court of Human Rights in Durisotto v. Italy. ${ }^{[58]}$ This case concerns a patient's appeal to a ruling of an Italian court that denied the patient access to an unproven stem cell treatment, based on an alleged infringement of several articles of the European Convention of Human Rights. The judgment made it clear that patients do not have an automatic right (on compassionate grounds) to a stem cell treatment that lacks evidence of efficacy. Mr Nivio Durisotto, whose daughter (the patient) suffers from a degenerative brain disease, insisted that his daughter was entitled to receive a controversial stem cell treatment offered by the Stamina Foundation. Dismissing Mr Durisotto's claim, the court stated that the Italian ruling rightly pursued the legitimate aim of protecting health and that the ruling was proportionate to this aim. Despite the emphasis on demonstrated efficacy, the court did not distinguish between compassionate treatments and unproven therapies, except to confirm that unproven therapies may not be used for compassionate purposes.

The increase in unsafe individualised treatments or experimental treatments offered to patients outside of the scope of a medicines regulatory framework demonstrates that, once again, clarity is required, as the laws and regulations governing medical practice and the conduct of healthcare professionals may not always be sufficient to address these issues.

\section{Conclusion}

This paper is premised on the assumption that a comparative understanding of the global regulatory framework with regard to stem cell research and therapy will assist in formulating more effective, better harmonised and ethical legal responses to a very complex and rapidly evolving scientific field. The paper first considered a few issues that raise specific ethical concerns, which include, among others, moral perceptions regarding the human embryo, reproductive and therapeutic cloning, oocyte donation, intellectual property rights in tissues and cells and issues relating to privacy, confidentiality and informed consent.

A comparative overview focusing on 35 selected jurisdictions was undertaken next, using as a yardstick for comparison the permissibility or prohibition of specific stem cell research activities in these countries including the creation of human embryos through processes such as IVF and SCNT and the resulting derivation of hESC lines. A distinction was drawn between so-called liberal and permissive regulatory regimens (e.g. those that permit embryo research and the derivation of hECS from various sources and technologies, such as IVF and SCNT); moderate regimens that follow a regulatory compromise (e.g. those that may permit research using excess IVF embryos, but prohibit hESC derivation from other sources); and finally, those restrictive jurisdictions that prohibit embryo research and related activities (e.g. the use of excess IVF embryos in hESC research and the derivation of hESC lines). This comparative overview illustrates that issues on which legal and policy variance is the most divergent are the moral and legal status of the human embryo and the patenting of human tissues, whereas consensus appears more evident with regard to the prohibition of reproductive cloning. In addition, it emerges that the transnational sharing of stem cell lines and data across jurisdictions will depend on the success with which jurisdictions succeed in harmonising laws and policies in key areas, most notably those relating to research oversight, technical standards, quality assurance and operating procedures.

The discussion on the legal regulation of stem cell-based products reveals very specific and unique challenges that make the traditional pharmaceutical regulatory model a poor fit for the clinical translation of stem cells. Firstly, issues revolving around product classification need to be clarified, as novel stem cell products may exhibit complex characteristics that could belong to more than one of the existing product classifications (e.g. medicines and medical devices). Clear, flexible and predictable guidelines and definitions are necessary to 
deal with these overlapping, combination or borderline products, considering the likelihood the new product types may defy existing product classifications. Secondly, the position with regard to the regulation of novel and individualised stem cell products or treatments should also be more transparent, particularly in view of the proliferation of unsafe or potentially harmful experimental treatments offered to vulnerable patients, which generally fall outside of the scope of the regulation of medicines. The recent judgment of the European Court of Human Rights concerning a patient's claim to have access to an unproven experimental stem cell treatment demonstrates how unsettled the current legal regulatory framework relating to stem cell therapies is, not to mention the need to strike a balance between patient expectations and entitlements with regard to unproven treatments and the broader objective of the protection of vulnerable patients from unsafe and potentially harmful treatments. The regulation of these exemptions should not be exploited, particularly if there is no reasonable justification for subjecting the patient to serious unforeseen risks. Thirdly, different understandings of key concepts in the regulatory context, such as 'minimally manipulated' cells or cells 'prepared on a non-routine basis' provide another obstacle.

The swiftly evolving field of stem cell research and therapy will continue to place high demands on regulators and policymakers to provide clear and unambiguous, yet flexible rules and guidelines. A balance will need to be achieved between governing stem cell research and not impeding its clinical translation. There is no doubt that collaborative efforts, some of which are referred to in this paper, will yield the most promising results in providing harmonised solutions to some of the legal lacunae and ambiguities referred to herein. Considered a permissive legal system as far as stem cell research is concerned, South Africa specifically needs to take cognisance of the lessons and shared best practices emanating from the global domain.

Funding. This research and the publication thereof is the result of funding provided by the Medical Research Council of South Africa in terms of the MRC's Flagships Awards Project SAMRC-RFA-UFSP-01-2013/ STEM CELL.

\section{References}

1. Isasi RM. Policy interoperability in stem cell research: Demystifying harmonization Stem Cell Rev 2009;5(2):108-115. [http://dx.doi.org/10.1007/s12015-009-9067-z]

2. Caulfield T, Zarzeczny A, McCormick J, et al. The stem cell research environment: A patchwork of patchworks. Stem Cell Rev 2009;5(2):82-88. [http://dx.doi. org/10.1007/s12015-009-9071-3]

3. Caulfield T, Zarzeczny A, McCormick J, et al. International stem cell environments: A world of difference. Nature Reports Stem Cells 2009;4. [http://dx.doi.org/10.1038/ stemcells.2009.61]

4. Cohen CB. Renewing the Stuff of Life: Stem Cells, Ethics, and Public Policy. Oxford: Oxford University Press, 2007:140.

5. Isasi RM, Knoppers, B. Beyond the permissibility of embryonic and stem cell research: Substantive requirements and procedural safeguards. Hum Reprod 2006; 21(1):2747-2481. [http://dx.doi.org/10.1093/humrep/del235]

6. Trounson C, Baum E, Gibbons, D, et al. Developing a case study model for successful translation of stem cell therapies. Cell Stem Cell 2010;6(6):513-516. [http://dx.doi.org/10.1016/j.stem.2010.05.008]

7. Kiatpongsan S, Sipp D. Monitoring and regulating offshore stem cell clinics, Science 2009;323:1564-1565. [http://dx.doi.org/10.1126/science.1168451].

8. Lomax G, McNab A. Harmonizing standards and coding for hESC research. Cell Stem Cell 2008;2(3):201-203. [http://dx.doi.org/10.1016/j.stem.2008.02.002]

9. Pardo R, Calvo F. Attitudes toward embryo research, worldviews, the moral status of the embryo frame. Science Communication 2008;30(1):8-47. [http://dx.doi. org/10.1177/1075547008319432]

10. Slabbert M. Cloning and stem cell research: A critical overview of the present legislative regime in Australia and the way forward. J Law Med 2003;10(4):514-530.
11. Slabbert M. The fetus and embryo: Legal status and personhood. Tydskrif vir die Suid-Afrikaanse Reg (Journal of South African Law) 1997;2:234-255.

12. Republic of South Africa. National Health Act 61, Section 1. Pretoria: Government Gazette 2003.

13. Australia. Section 1, Research Involving Human Embryos Act No 145 of 2002 (Cth). 14. Indian Council of Medical Research. Guidelines for Stem Cell Research (2012) India: Indian Council of Medical Research, 2012. http://icmr.nic.in/stem_cell/ stem cell guidelines.pdf (accessed 2 January 2015).

15. Republic of South Africa. Human Cloning and Other Prohibited Practices Act Government Gazette 2 September 2004

16. Isasi MR, Knoppers BM. Mind the gap: Policy approaches to stem cell and cloning research in 50 countries. Eur J of Health Law 2006;13(1):9-26. [http://dx.doi. org/10.1163/157180906777036328]

17. European Union. Judgment of the Court of Justice of the European Union, Grand Chamber. Case 6-364/13 (18 December 2014). http://curia.europa.eu/juris/ document/document.jsf?text $=\&$ docid $=160936 \&$ pagelndex $=0 \&$ doclang $=E N \& m$ ode $=$ req \&dir $=\&$ occ $=$ first $\&$ part $=1 \& c i d=61843$ (accessed 24 January 2015).

18. International Stem Cell Corporation v. Comptroller General of Patents, Designs and Trade Marks [2013] EWHC 807. http://www.bailii.org/ew/cases/EWHC/ $\mathrm{Ch} / 2013 / 807 . h t m l$ (accessed 24 January 2015)

19. Lo B, Parham L. Ethical issues in stem cell research. Endocr Rev 2008;30(3):204-225. [http://dx.doi.org/10.1210/er.2008-0031].

20. Tashibana $M$, Amato $P$, Sparman $M$, et al. Human embryonic stem cells derived by somatic cell nuclear transfer. Cell 2013;153(6):1228-1238. [http://dx.doi. org/10.1016/j.cell.2013.05.006].

21. United Nations. Declaration on Human Cloning. GA Res., UNGAOR, $59^{\text {th }}$ Sess., UN Doc. A/280 (2005). http://www.un.org/press/en/2005/ga10333.dochtm (accessed 27 July 2015).

22. Schlesinger F. I have cloned a human: Extraordinary claims of a doctor who 'has implanted embryos into four women'. Mail Online; 22 April 2009. http://www. dailymail.co.uk/sciencetech/article-1172487/Ive-cloned-human-Astonishing claims-doctor-implanted-embryos-women.html (accessed 3 January 2015).

23. Hyun I. Moving human SCNT research forward ethically. Cell Stem Cell 2011;9(4):295-297. [http://dx.doi.org/10.1016/j.stem.2011.08.001]

24. Van der Heyden MAG, van de Ven T, Opthof T. Fraud and misconduct in science: The stem cell seduction. Netherlands Heart Journal 2009;17(1):25-29. [http:// dx.doi.org/10.1007/BF03086211]

25. Botman O, Wyns C. Induced pluripotent stem cell potential in medicine specifically focused on reproductive medicine. Front Surg 2014(1):1-10. [http:// dx.doi.org/10.3389/fsurg.2014/00005]

26. The Hinxton Group. Proprietary challenges in stem cell research. Baltimore; The Hinxton Group. https://hinxtongroup.wordpress.com/background-2/iplandscape/ (accessed 5 January 2015)

27. Expanded Appeal Board, European Patent Office (EPO). Case G0002/06 (Use of embryos/WARF) of 25 November 2008. http://www.epo.org/law-practice/ case-law-appeals/recent/g060002ex1.html (accessed 6 January 2015).

28. European Union. Court of Justice of the European Union (2011). Oliver Brüstle v. Greenpeace eV. Judgment of the Court (Grand Chamber), 18 October 2011 (Case C-34/10). http://eurlex.europa.eu/LexUriServ/LexUriServ.do?uri=CELEX:62010CJO 034:EN:HTML (accessed 6 January 2015).

29. Moore v. Regents of the University of California 51 Cal. 3d. 120, 793 P.2d. 479, 27 Cal. Rptr. 146, CA. 1990

30. Dahl v. Angle 222 Ore App 572 (Or Ct App, 2008)

31. Hecht v. Superior Court of Los Angeles County, 20 Cal Rptr 2d 275 (Cal Ct App, 1993).

32. Australia. Supreme Court of Western Australia. Ex parte C [2013] WASC 3 (2 January 2013)

33. Yearworth v. North Bristol NHS Trust [2009] 3 WLR 118.

34. Canadian Institutes of Health Research, Natural Sciences and Engineering Research Council of Canada. Tri-Council Policy Statement. Ethical Guidelines for Research involving Humans. Ottowa: Government of Canada, 2014: Chapter 12. http://www. pre.ethics.gc.ca/pdf/eng/tcps2/TCPS_2_FINAL_Web.pdf (accessed 27 July 2015).

35. International Society for Stem Cell Research. Guidelines for the Conduct of Human Embryonic Stem Cell Research. ISSCR; 2006:par 11.2. http://www.isscr.org/home/ publications/guide-clintrans (accessed 27 July 2015).

36. Caulfied T, Ogbogu U, Isasi R. Informed consent in embryonic stem cell research Are we following basic principles? CMAJ 2007;176(12):1722-1725. [http://dx.doi. org/10.1503/cmaj.061675]

37. Aalto-Setälä K, Conklin BR, Lo B. Obtaining consent for future research with induced pluripotent cells: Opportunities and challenges. PLos Biol 2009;7(2):e42. [http://dx.doi.org/10.1371/journal.pbio.1000042]

38. Hourd P, Chandra A, Medcalf N, et al. Regulatory challenges for the manufacture and scale-out of autologous cell therapies. In:The Stem Cell Research Community. StemBook. June 30, 2014. http://www.stembook.org/node/5702 (accessed 4 January 2015). [http://dx.doi.org/10.3824/stembook.1.96.1].

39. Isasi R, Knoppers BM. From banking to international governance: Fostering innovation in stem cell research. Stem Cells Int 2011;498132:1-8 [http://dx.doi. org/10.4061/2011/498132]. 
40. International Conference on Harmonisation of Technical Standards for Registration of Pharmaceuticals. http://www.ich.org/home.html (accessed 2 February 2015).

41. European Parliament and Council of the European Union. ATMP Regulation (EC) 1394/2007, Part IV, Annex to Directive 2001/83/EC, adopted 14 September 2009 (as amended). http://ec.europa.eu/health/index en.htm (accessed 27 July 2015).

42. European Parliament and Council of the European Union. ATMP Regulation, article 28(2), amending article 3 of Directive 2001/83. (2001). http://ec.europa.eu/ health/index_en.htm (accessed 27 July 2015).

43. European Parliament and Council of the European Union. Directive 2004/23/ EC. (2004). http://ec.europa.eu/health/blood_tissues_organs/key_documents/ index_en.htm (accessed 27 July 2015).

44. European Parliament and Council of the European Union. Directive 93/42/ EEC. (1993, article 1.5(f)). http://eur-lex.europa.eu/legal-content/EN/ NOT/?uri=CELEX:31993L0042 (accessed 27 July 2015).

45. US Food and Drug Administration. Draft Guidance for Industry - Same Surgical Procedure Exception under 21 CFR 1271.15(b): Questions and Answers Regarding the Scope of the Exception. (2014). http://www.fda.gov/BiologicsBloodVaccines/ GuidanceComplianceRegulatoryInformation/Guidances/Tissue/ucm419911.htm (accessed 15 January 2015).

46. EUR-Lex. Access to European Union Law. http://eur-lex.europa.eu/legal-content/ EN/ALL/?uri=CELEX:32004L0023 (accessed 6 February 2015).

47. United States v. Regenerative Sciences, LLC, No 12-5254 F 3d (D.C. Cir. 2014).

48. US Food and Drug Administration. Draft guidance for industry - Individual patient expanded access: Form FDA 3926. (2015). https://www.federalregister.gov/ articles/2015/02/10/2015-02561/individual-patient-expanded-access-applicationsform-fda-3926-draft-guidance-for-industry 2015 (accessed 27 July 2015).

49. US Food and Drug Administration. Guidance document - 'Off-label' and investigational use of marketed drugs, biologics and medical devices 2014. http:// www.fda.gov/Regulatorylnformation/Guidances/ucm126486.htm (accessed 25 January 2015).

50. US Food and Drug Administration. Draft guidance - Human Cells, Tissues, and Cellular and Tissue-Based Products (HCT/Ps) from Adipose Tissue: Regulatory Considerations 2014. http://www.fda.gov/BiologicsBloodVaccines/
GuidanceComplianceRegulatorylnformation/Guidances/Tissue/ucm427795 htm\#INTRO (accessed 25 January 2015).

51. US Food and Drug Administration. Draft guidance - Minimal Manipulation of Human Cells, Tissues, and Cellular and Tissue-Based Products 2014. http://www. fda.gov/BiologicsBloodVaccines/GuidanceComplianceRegulatorylnformation/ Guidances/CellularandGeneTherapy/ucm427692.htm (accessed 25 January 2015).

52. Feigal EG, Tsokas G, Viswanathan S, et al. Proceedings: International regulatory consideration on development pathways for stem cell therapies. Stem Cells Transl Med 2014;3(8):879-887. [http://dx.doi.org/10.5966/sctm.2014-0122]

53. Von Tigerstrom B. The challenges of regulating stem cell based products. Trends Biotechnol 2008;26(12):653-659. [http://dx.doic.org/ 10.1016/j. tibtech.2008.08.004]

54. European Union. Report from the EC to the European Parliament and the Council in accordance with Article 25 of Regulation (EC) No 1394/2007 of the European Parliament and of the Council on advanced therapy medicinal products and amending Directive 2001/83/EC and Regulation (EC) No 726/2004 (28 March 2014). http://ec.europa.eu/health/files/advtherapies/2014_atmp/atmp_en.pdf (accessed 6 February 2015).

55. US Food and Drug Administration. Draft guidance - Minimal Manipulation of Human Cells, Tissues, and Cellular and Tissue-Based Products . (2014). http://www. fda.gov/BiologicsBloodVaccines/GuidanceComplianceRegulatorylnformation/ Guidances/CellularandGeneTherapy/ucm427692.htm (accessed 25 January 2015).

56. Lysagth T, Kerridge I, Sipp D, et al. Oversight for clinical uses of autologous adult stem cells: Lessons from international regulations. Cell Stem Cell 2013;13:647-651. [http://dx.doic.org/10.1016/j.stem.2013.11.013]

57. Cuende N, Boniface $C$, Bravery $C$, et al. The puzzling situation of hospital exemption for advanced therapy medicinal products in Europe and stakeholders' concerns. Cytotherapy 2014;16(12):1597-1600. [http://dx.doi.org/10.1016/j. jcyt.2014.08.007]

58. European Court of Human Rights. Durisotto v. Italy. Application no 62804/13. ECHR 153 (2014). http://hudoc.echr.coe.int/sites/eng-press/pages/search. aspx?i=003-4774464-5811888\#\{"itemid":["003-4774464-5811888"]\} (accessed 6 February 2015). 